\title{
Use of Songs Media in Listening Learning Iin Class III Elementary School
}

\author{
Iqbal Yusca Ismail ${ }^{1}$, Vismaia S. Damayanti ${ }^{2}$ \\ Universitas Pendidikan Indonesia \\ iqbalyusca@upi.edu,vismaia@upi.edu
}

\begin{abstract}
This research based on low of student's listening skill in learning English at Madrasah Ibtidaiyah Al-Falaah Kopo. The learning process seems just apply teacher centered method. It makes students unmotivated in learning English especially in listening skill. Therefore, the researcher make serious efforts to use songs in teaching listening in order to make the learning process being fun and interesting. The aims in this research is to get the description of student's learning outcome improvement in teaching listening using song as a media. The research used classroom action research with Elliot models by implementing three cycles and there are three actions in each cycles. The subject of this research were 3th grade students of Madrasah Ibtidaiyah Al-Falaah Kopo consist of 17 male students and 17 female students. Based on the result of this research, it can be concluded that there is an improvement in the score average of the students. In the first cycle, student's average is 60 , and second cycle is 64 , and in the third cycle is 75 . Therefore the use of songs as a media could improve student's learning outcomes and it can be a recommendations or suggestions for teachers to teach English or in other education research.
\end{abstract}

Keywords: Media, Songs, Listening Skill, Fun Learning, Elementary School, Madrasah Ibtidaiyah, Indonesia

\section{Introduction}

Learning English in Indonesia is included in the Education Unit Level Curriculum as a local content taught to students in Indonesia. In the Education Unit Level Curriculum, English aims to: 1) Introduce English as an International language; 2) To equip students to be able to speak English. (Ministry of National Education, 2006, p. 6). In addition, according to Sukamerta (2011) learning English is reinforced by the policy of the Ministry of Education and Culture of the Republic of Indonesia No. 0487/1992, Chapter VIII, which states that elementary schools are possible to add subjects that do not conflict with national education goals.

There are four essential language skills in English language learning and skills each has a different difficulty. The four skills are listening skills, speaking skills, reading skills, and writing skills. Listening be the first foundation that must be understood by the learner.

Listening is an important aspect of learning English. As stated by Rost (2011, p. 1) which states that "there is no spoken language without listening". Linse (2005, p. 24) also states that listening and reading are receptive abilities because the focus of listening and reading is receiving information from outside sources. While speaking and writing 
are productive capabilities because through them, information has been obtained from listening and reading are also processed into a writing and speech.

The fact that happened on the ground based observations that have been done in SDIT Al-Falaah Kopo, most of students do not have the listening skills. When teachers provide instruction in English, students were confused about what was instructed by the teacher. It causes learning is not running optimally. Besides that, lack of students' ability in listening skills, student vocabulary in English is very lacking. Based on the description above, this causes difficulties in teaching students conducted by the teacher. In addition, the study is only done with the lecture method, and only centered on the teacher.

Due to the lack of learning facilities and infrastructure, learning only relies on textbooks provided by the school. Some students look bored because of the lack of reference to the subject matter and are not enthusiastic in the teaching and learning process carried out by the teacher. Whereas in listening learning itself, the media used in learning is considered very important to more easily deliver learning objectives to be delivered by the teacher. Encyclopedia of Educational Research in Hamalik quoted Arsyad (2002, p. 25) suggests that the benefits of learning media itself can provide a real experience to students and can also help the growth of understanding that can help the development of language skills. Therefore, the use of media is very important to use in learning, especially learning listening in elementary school.

The use of media songs in listening learning is considered appropriate to answer the problems mentioned. The song used by the teacher is also adapted to the theme being taught in elementary school. The songs that are taught are adjusted to the target of achieving student vocabulary that is considered difficult. In addition, so that students better understand the vocabulary learned, the use of media songs will be combined with the help of various other media such as flash cards, images, and other media that help students better understand the vocabulary taught.

Based on the description stated above, the problem in this study is how the use of media songs in learning listening can improve listening skills in SDIT Al-Falaah Kopo. The purpose of this study is to obtain an overview of the learning outcomes of class III SDIT Al-Falaah Kopo in Listening learning using media songs.

As a foreign language that students have just learned at the elementary school level, teachers are required to be able to provide a pleasant and interesting English language experience for students as an initial impression in learning English in elementary schools so students feel easy and happy in learning English. Scott and Ytreberg (2003, p. 5) suggest that the concentration of students in learning is quite short so learning that is only delivered verbally is not enough. In learning English as a foreign language, teachers are required to design fun learning such as the use of songs or games in learning English so that learning becomes more fun and meaningful (Philips, 1993, p. $5)$.

The media used by teachers also play an important role in learning English in elementary schools. There are many types of media that are often used as a tool in learning English such as flashcards, songs, puppets, stories, and pictures. In the use of 
media, teachers must also pay attention to the care and maintenance of media that are made so that they can be used repeatedly and last for a long time (Hermawan, Zaman and Riyana, 2007, pp. 43-44).

The method of learning English using songs is also able to help students to improve listening skills and pronunciation. Besides that, it is also able to help students improve speaking skills in learning English (Murphey, 1992). Therefore, it can be concluded that learning listening through songs is able to improve the aspects of Listening and Speaking students in a more enjoyable way.

\section{Method}

The research on media songs in listening learning was conducted at SDIT Al-Falaah Kopo located on Jalan Raya Soreang Cipatik Km. 03 No. 28 Kmp. Kopo Kecamatan Kutawaringin, Kabupaten Bandung. The subjects of the study were 34 grade III students of Ibtidaiyah Al-Falaah Madrasah consisting of 17 men and 17 women.

The method is the Class Action Research (CAR) or PTK method. The model used by researchers in the PTK carried out was the model. This model starts from the discovery of a problem which is then carried out planning actions to be carried out and considered capable of solving problems. After carrying out the action, then monitored and given action again if deemed necessary. The stages in the PTK of the Elliot model include initial ideas, findings of analysis, planning, implementation, monitoring implementation and their effects, as well as reflection on each action.

The research instrument used by researchers to collect data from the results of the study included interview sheets, observation sheets, worksheets, and also documentation tools. In addition, research data collection techniques are carried out by observation, interviews, evaluations, and also documentation. The data that has been obtained by the researcher is then processed by qualitative techniques obtained from observation sheets, interviews, or field notes which are then analyzed and presented descriptively. In addition, the quantitative data obtained through the evaluation sheet in the form of worksheets are processed using the average formula.

Results from quantitative and qualitative data are then combined with triangulation techniques. Research can be said to succeed if the standard of success can be achieved in three cycles. The standard of success or KKM in a cycle is if $85 \%$ of students are able to achieve the specified KKM. KKM used in learning English in class III is 70.

\section{Result And Discussion}

\subsection{Results}

The research was conducted in three cycles. Each cycle consists of three actions. In the first cycle the researchers took the theme of parts of the body. There are 10 vocabularies that are the target of learning. The learning media are presented in the form of songs and various flashcards. Flashcards used in each action in the form of paper print out images of vocabulary taught to students. The flashcards are $15 \mathrm{~cm}$ long and $21 \mathrm{~cm}$ wide. In addition, to be able to be reused on another day, the flashcards are coated with used 
boxes to be sturdy and not easily worn out. Researchers also use laptops, sound speakers, and also various interactive videos as supporting media in the research carried out.

The results of the research in the first cycle showed that students were still awkward and embarrassed in the learning process so that it had an impact on the learning outcomes achieved by students. In addition, in the evaluation activities, students are still confused with the instructions conveyed by the researcher, therefore the researcher demonstrates first the procedure for the worksheet so that students understand what should be done when the evaluation activities are carried out.

In the second cycle the researchers took the theme of things in the kitchen. There are 10 vocabularies that are the target of learning. The results of the study in this second cycle were students who were still reluctant to come to the front of the class when the researchers asked students to sing. This is because students are afraid of being wrong in the pronunciation of the lyrics and are afraid of being scolded. In addition to that, student pronunciation is still inaccurate so researchers repeatedly give examples of the pronunciation of the vocabulary taught to students.

In the third cycle the researcher took the theme of vegetables. There are 10 vocbularies that are the target of learning. The results of the research in the third cycle there are several shortcomings and also improvements in the learning that is carried out. The shortcomings in the third cycle of learning include the pronunciation of students who are still wrong so that further action is needed in improving the pronunciation of students. The advantage is that students are familiar with various activities carried out by the teacher. In addition, students have understood various procedures such as the worksheet, greetings, and concluding learning procedures.

The assessment of student learning outcomes in each cycle experienced an average increase. Student learning outcomes on listening learning using media songs can be seen in the following graph.

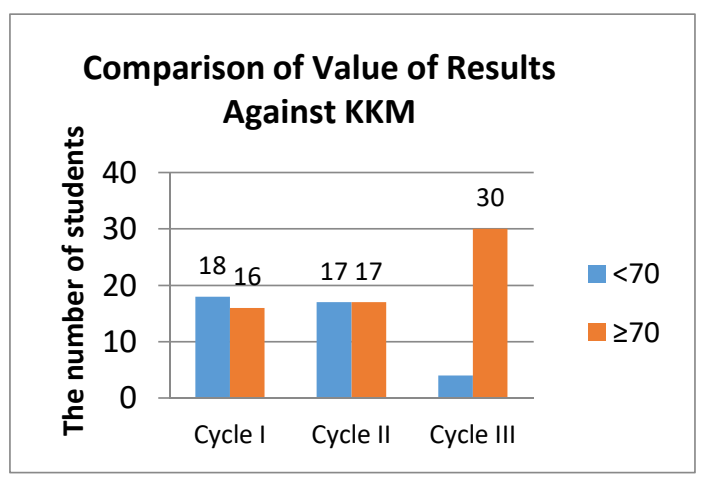

Figure 1. Comparison of Value of Results Against KKM

\subsection{Discussion}

Based on the diagram above, in the first cycle the average grade value achieved by students was 60 . There were 18 students $(52.95 \%)$ who had not reached the minimum completeness requirement, namely 70 and there were 16 students $(47.05 \%)$ who were 
able to reach minimum grade completeness requirements. In the second cycle, the average grade score achieved by students was 64 . There were 17 students $(50 \%)$ who had not reached the minimum completeness requirements and there were 17 students $(50 \%)$ who achieved the minimum completeness requirements. In the third cycle, the average grade score achieved by students is 75 . There are 4 students $(12 \%)$ who have not met the minimum completeness requirements while 30 students $(88 \%)$ meet the minimum completeness requirements.

Based on the results of these studies, it is evident that the use of media songs in learning listening can improve student learning outcomes. This is similar to what Nurhayati (2009) stated that music is an important part of learning English because music makes students more sensitive to sound, and learning languages is nothing but learning various types of sound that are meaningful. Songs can also make the class more interesting and lively. When children like the song given by the teacher, students will be happy and enthusiastic in singing it. With students singing songs presented by the teacher, that's when students will not realize that they are learning the language. Apart from that, students prefer learning English by using songs compared to not using songs. Students reason by using songs, learning becomes more fun because students can sing while dancing when learning takes place. Moon (2000) states that when students like learning activities, students will be motivated and want to do the activity again and also it is something positive in learning.

\section{Conclusion}

Based on the results that have been obtained, the researcher draws conclusions based on the research that has been done. The following conclusions are answers to the formulation of the problem described previously. The conclusions of the research on the use of media songs in listenng learning are student learning outcomes using media songs in listening learning in class III of SDIT Al-Falaah Kopo which has increased in each cycle. In this case, it can be seen from the increase in class values. In the first cycle, students who achieved the KKM score were 16 students. In the second cycle there was an increase in the number of students who reached the KKM score of 17 students. While in the third cycle, the number of students who reached the KKM score was 30 students. The mean value of the class in each cycle also increases. In the first cycle KKM scores reached 60, while in the second cycle the students 'scores reached 64, and in the third cycle the students' grade scores reached 75. From these results it can be shown that the use of media songs in listening learning can improve student learning outcomes.

\section{References}

[1] Arsyad, Azhar. (2011). Media Pembelajaran. Jakarta: PT Raja Grafindo Persada.

[2] Depdiknas, (2006). Kurikulum Tingkat Satuan Pendidikan Sekolah Dasar; Mata Pelajaran Bahasa Inggris. Jakarta: Depdiknas

[3] Hermawan, A. Herry, Zaman, B,. dan Riyana, C. (2007). Media Pembelajaran Sekolah Dasar. Bandung: UPI Press.Zuchdi,

[4] Linse. (2005). Practical English Language Teaching: Young Learners. New 
York: McGraw-Hill ESL/ELT.

[5] Moon, J. (2000). Children Learning English. London: Macmillan Heinemann.

[6] Murphey, T. (1992). Music and Song. England: Oxford University Press.

[7] Nurhayati, L. (2009). Penggunaan Lagu Dalam Pembelajaran Bahasa Inggris Untuk Siswa SD; Mengapa dan Bagaimana. Majalah Ilmiah Pembelajaran nomor 1, Vol 5, Mei 2009.

[8] Philips, S. (1993). Young Learners. Oxford: Oxford University Press.

[9] Rost. M. (2011). Teaching and Researching Listening. London: Pearson Education Limited.

[10] Scott, A. W, dan Ytreberg, H, L. (2003). Teaching English to Children. New York: Longman.

[11] Sukamerta, M.I. (2011). Implementasi Kebijakan Penbelajaran Bahasa Inggris pada Sekolah Dasar di Kota Denpasar. Tesis, Universitas Udayana Bali 